of operation were unfavorable in most cases, antisepsis being very difficult.

$V$. IU uants, of Leipzig, has also seen very bad results of Hoffa's operations. As for abduction, the important point is the existence of caput and colles femoris. If the latter is wanting the results are bad, even when the cases are not operated.

V. BRAMAN , of Halle, has operated upon fourteen cases of grave character. One died of tuberculosis miliaris; the rest recovered. He had always good success in these operations up to children of 11 years of age.

$$
\text { ( } T o \text { be continued.) }
$$

B.

\section{Letter from Ex-President Hibberd-His Return Trip from San Francisco.}

To the Editor:-On June 11 some of the members of the American Medical Association who had return tickets via the Northern Pacific deemed it prudent to accept the arrangement by which their tickets would be honored over the Southern Pacific to Ogden and the Union Pacific to Butte, and on June 12 a larger number availed themselves of the same privileges. This was done for the reason that they discredited the statement that the flood damage to the Northern Pacific would be repaired by the time they arrived at Portland. With more faith about fifty of us took the evening train on June 1.2 for Portland, which we found still largely under water, but by a long steamer ride down the Willamette and Columbia Rivers-or where the rivers ought to be for the whole country was covered with water-the boat ran into what was usually a creek, and winding among the trees about five or six miles we reached a railroad bridge across the stream, disembarked on the moist earth, climbed into the train, went to bed and woke up next morning in Tacoma with our car on a side track at the wharf, and a steamer alongside to take the party down Puget's Sound to Victoria in Her Majesty's dominion, to return to Tacoma next morning. Having some arrangements to make for Pullman accommodations, myself and ladies remained in Tacoma during the day.

Completing our arrangements in Tacoma we left for the East on a belated train at 3 o'clock on the morning of June 16 , and arrived at Spokane the next morning to find the road still impassable between Spokane and Helena on both lines via Missoula and Butte, but the agents declaring they expected dispatches every hour notifying them of a restored road. We waited two days without apparent progress of repairs and then twenty-one of us accepted an order from the Northern Pacific on the Union Pacific, which by a round-a-bout line via Walla Walla, Umatilla on the Columbia River, and Pocatella, covering 1,200 miles, landed us at Butte, Mont., on the morning of June 20 . Leaving Butte at $9: 20$ A.M., June 21, we arrived at Bozeman at 1 P.M., to find that our connecting train was ten hours behind time and might be more. An earnest petition by wire to headquarters at St. Paul to continue our train to Livingston met with prompt response, making our train special, not only to Livingston but to Cinnabar, fifty-one miles further, when we were met by coaches which delivered us at Mammoth Hot Springs Hotel in the Yellowstone Park at 9:30 the same evenıng.

The next morning we left for the tour of the Park and returned on June 26 , to find all further progress arrested by the strike. Here we waited day after day. The hotel made us comfortable, but no mails and no newspapers, with wild rumors about every railroad in the United States being tied up, we felt the burden of imprisonment and isolation to an intense degree. On July 1, we organized the "Association of Distressed and Stranded Tourists" which embraced about 120 persons of both sexes, ladies predominating. The Association at once secured a limited report of the more impor. tant strike items wired to us from the press dispatches delivered at Anaconda 200 miles west. It was at once learned that the Great Northern Railroad was open from Helena to St. Paul, and Chicago entirely cut off from railroad travel. Helena could be reached by 182 miles staging over the erest of the Rockies, but notwithstanding the severity of the ride and its expense some of the imprisoned tourists began to leave, the first on July 2 , the number increasing from day to day, and so far as advised, all reached St. Paul in from five to seven days. At Helena, through an arrangement between the Northern Pacific and Great Northern Railroad, the tickets on the Northern Pacific were honored on the Great Northern, and parties found no diffculty getting through either to St. Paul or Chicago.

The whole number imprisoned in the Park at first was about 170 , all of whom ultimately reached the Mammoth Hot Springs Hotel, but many went to Livingston and then elsewhere as they could find conveyance. The largest number at the hotel at one time was 127.

On July 11 a mail came in, the first since June 26, and we received files of Helena and Anaconda papers to June 9, which gave us the first understandable account of the inauguration and progress of the strike. These papers with some belated letters were boons indeed.

After considerable telegraphing the railroad authorities on July 12 wired us that a train would be ready for us at Livingston to take us to St. Paul on the afternoon of July 13, but in consequence of washouts trains could not be sent to Cinnabar for an indefinite time, so we packed our trunks for a sixty mile stage ride.

Thirty-five of us left the hotel at 7 A.M. on July 13, arrived at Livingston at 10 P.M., the latter part of the road being very tedious, miles of it deep mud and water from a cloudburst the evening before. A merchant on an unpaved street told me the water in front of his place was three feet deep, coming on to his porch. This was the second cloudburst in three weeks.

We supposed from our telegrams the train would be waiting for us at Livingston, but on arrival were informed that it would not be in until the 14th some time.

A train came in from St. Paul on July 14 at 4 o'clock and left about 5. Before the train reached the station the soldiers formed in line on each side of the track, a man fully armed every fifteen feet, and remained on guard until the train left.

At 10 o'clock P.M. our train arrived from the west and the soldiers guarded it as they did the westbound. When the train went west two days before a striker crowded on to the guard line and refused to leave, using defiant and abusive language to the commanding officer, who then cut his head with a saber. Our train was guarded until it left at 1 A.M. on July 15.

This was the first we had witnessed of the actual use of soldiers. True, troops at the Hot Springs in the Park had received marching orders at 4 P.M. on July 7 , and at 7 o'clock were in the saddle and off, the public knew not where, but we guessed, and have since learned they were guarding the Bozeman tunnel. Ours was the first train East since the strike, and was picking up delayed travelers wherever it found them. Next morning we found our train consisted of sixteen cars of all kinds and under guard of soldiers carried on board-as every train was-and every bridge, trestle and important culvert guarded by soldiers, and large bodies of troops concentrated at strategic points. The dining ear with us had its hands full to feed the promiscuous company aboard, but it was the only resource.

At an early hour Monday morning, July 16, we passed Bismarck, and being out of Montana and out of danger, had left our military guard at Mandan. 
From Bismarck our trip was uneventful, and we arrived at St. Paul at 1:30 o'clock on Tuesday morning, and as the railroad authorities offered tourists who wished to take the early trains East the privileges of their sleepers and accommodations for the night, our party with others accepted, and with an early start arrived in Chicago at $9: 45$ P.M., July 17 well and in good condition, and expect to reach home after an absence of fiftyntwo days.

We left about thirty tourists at the Mammoth Hot Springs Hotel in the Park; there were no physicians among then, but we found several at Livingston awaiting the first train. Dr. Montgomery took a census of our train and reported ten members of the American Medical Association on it with nine ladies, and four tourists, doctors, with thirty-four other gentlemen and ladies who had been prisoners in the Park with us. J. F. HibBerd, M.D.

\section{Beaumont Medical College.}

St. Louis, Mo., July 10, 1894.

To the Editor:-Dr. W. B. Outen, Dean, requests me to say "that some months ago there appeared what purported to be an unofficial announcement from St. Louis that the Beaumont Hospital Medical College was about to close its doors. Had this statement come to my knowledge before now, I should certainly have asked for its immediate correction, for it had no foundation in fact and must have been promulgated by some one who intended that the Beaumont Medical College should be injured by the publication. Far from closing its doors our school is in a most fourishing condition. We have been so fortunate as to have secured from those interested in higher medical education, such financial assistance as practically to place the school on a firm financial basis, and to insure its perpetuity. We have never been the competitors of those who heralded their schools and incidentally their personality to the medical public. We have gone along the even tenor of our way doing conscientious and, we believe, good work in the cause of medical education, and we feel aggrieved to think that your Joursal would publish, without proper inquiry, a statement which is calculated to do us an injury, and we respectfully request that you give to this denial as much prominence as was given the original statement." REVOCATION OF LICENSE.

The Secretary of the State Board of Health, of Missouri, has been instructed at our last meeting at Kansas City, to furnish to your Jourval the proceedings, more especially that portion of them which relate to the revocation of the license to practice in our State, of Dr. J.P. Henderson, a resident of Chicago, who was an itinerant for the last six months in Missouri, Dr. Henderson was a regular graduate and a licentiate of the Illinois State Board of Health, and is President of the Illinois State Institute of Medicine and Surgery. He registered in this State upon a diploma and letters of recommendation from medical men of Chicago and then spread his advertisements broadcast. Physicians of Nevada, Vernon County, Missouri, called the attention of the Board to his advertisements which were so worded as to mislead the public. After a hearing, the Board unanimously decided to revoke his license for unprofessional conduct. Our State has too long been the refuge of just such fellows, and the Board proposes in future to enforce the law, and to protect our people.

(Signed)

F. J. Lutz, M.D.,

President State Board of Health, of Missouri.

\section{North Texas Medical Association.}

Sherman, Texas, July $10,1894$.

To the Editor:-Having just received the last number of the Journal of the American Medical Association, I notice in it an account of the meeting of the North Texas
Medical Association which was held in this city on June 19 , 20,21, which notice does the Association an injustice as the program which I enclose will prove. All the papers therein contained were read except those marked out, and a number of cases reported not on the program, all of which were discussed.

There were in fact more than one hundred members present, instead of seventy-five as stated.

This Association meets semi-annually. The next meeting will be held at Gainesville the second Tuesday in December. Yours very truly, J. T. WILSox, M.D.

\section{Sanitarium in New York.}

To the Editor:-The Sanitarium concerning which your correspondent, N. H. P., makes inquiry in the Journal of July 7 , page 37 , is probably that under the care of Dr. E. L. Trudeau, at Saranac Lake, New York.

A. H. E.

\section{SOCIETY PROCEEDINGS.}

\section{Medical Society District of Columbia. Report on Typhoid Fever. \\ [Continued from page 82.]}

2. The relations of the mortality of typhoid fever and its distribution in different sections of the city to the pollution of the soil by the leakage from privies, and to the drinking of contaminated well water.

The truth of the theory may be considered as established that there is a relationship between pollution of the soil with human excrement and the drinking of well water con. taminated with the poison of typhoid fever contained in this excrement. The converse of this has also been absolutely proved that typhoid fever can be diminished-almost elim. inated-by a proper purification of the soil and the drinking of pure water. Facts will be alluded to further on, which will illustrate this point.

Out of a total of 1,174 squares in Washington and Georgetown, deaths from typhoid fever occurred in 426 squares, or one death in about two and two-third squares.

If the city is arbitrarily divided into four sections, Georgetown making the fifth, and the number of deaths from typhoid fever during the last five years be marked in the localities in which they occurred, it will be seen that there is a great difference in the distribution of mortality. In region 1 (all that part of the city south of East Capitol Street, and the public grounds, including the southeast and southwest parts of the city), there are a very large number of cases. In this area there were 197 fatal cases in 131 squares, and in region 2 (east of North Capitol Street and north of East Capitol Street) in 59 squares there were 84 deaths. In region 3 , comprehending all that part west of North Capitol Street and east of Thirteenth Street and north of the public grounds, in 116 squares there were 179 cases. In region 4 , west of Thirteenth Street to Georgetown and north of the river to Florida A venue, in 82 squares there were $11+$ deaths. In Georgetown in 39 squares there were 52 fatal cases. Assuming that each death represents 10 cases of typhoid fever, in the five years there were about 6,260 cases in Washington, at the rate of over 1,200 cases a year. Of these there were nearly 400 cases a year in the southeast and southwest districts, 170 in the northeast. 360 in the middle region, 230 in the northwest, and 100 in Georgetown, 400 in hospitals and public institutions, and 190 in the county. If we add the cases occurring in hospitals and the county to those in the city proper we have a total of 9.220 cases in five years, an annual average of 1,444 cases.

The percentage of deaths from typhoid fever in each of these divisions to the contained population is :

\begin{tabular}{|c|c|c|c|}
\hline Region. & $\begin{array}{l}\text { Population of } \\
\text { region. I'olice } \\
\text { census } 1892 .\end{array}$ & $\begin{array}{l}\text { Total deaths } \\
\text { from typhoid } \\
\text { fever in five } \\
\text { years in each } \\
\text { regiou. }\end{array}$ & $\begin{array}{c}\text { Annual rate of } \\
\text { mortality to } \\
10,000 \text { popula- } \\
\text { tion in each } \\
\text { region. }\end{array}$ \\
\hline $\begin{array}{l}\text { I. (South) . . } \\
\text { II. (N. East) } \\
\text { III. (Central) } \\
\text { IV. (N. West). } \\
\text { V. (Georgetown) } \\
\text { County. . . . }\end{array}$ & $\begin{array}{l}62,218 \\
20,278 \\
70,865 \\
49,969 \\
16,344 \\
30,429 \\
\end{array}$ & $\begin{array}{r}197 \\
84 \\
179 \\
114 \\
52 \\
95\end{array}$ & $\begin{array}{l}1.3 \\
6.2 \\
5.0 \\
4.6 \\
6.3 \\
6.2 \\
\end{array}$ \\
\hline
\end{tabular}

